\title{
CONSULTANCY REPORT ON
}

\author{
GHAZIABAD FARMS
}

Prepared by:

Dr. Enrique Figueroa

Prepared for:

Agricultural Cooperative Development International 50 F Street, N.W.

Suite 900

Washington, D.C. 20001

Phone: (202) 638-4661

August, 1991

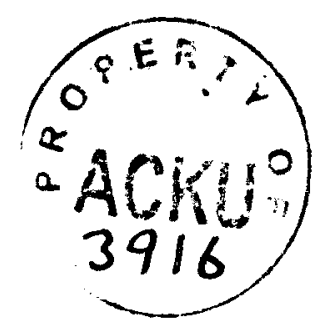


TABLE OF CONTENTS

Executive Summary

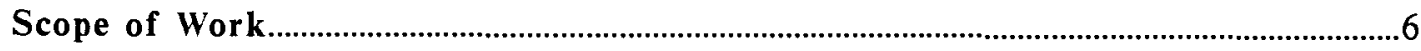

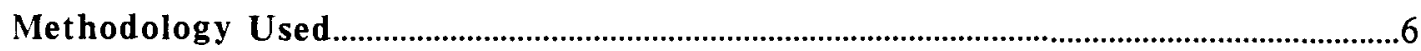

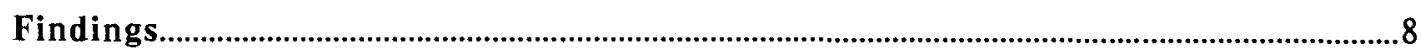

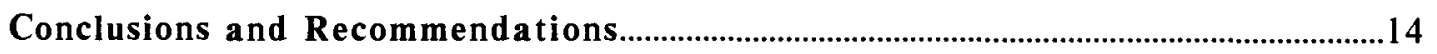

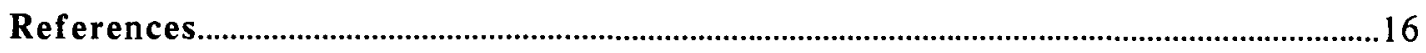

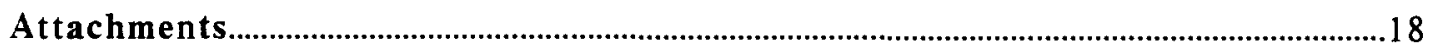

Letter from President Gollehon defining work to be done

Figure I. World Production of Major Olive Oil Producers, 1980-86

Figure II. Average Country Shares of World Olive Oil Production, 1981 to 1986

Figure III. World Exports of Olive Oil By Country of Origin: 1970 to 1986

Figure IV. World Imports of Olive Oil By Importing Countries: 1980 to 1986

Table I. World Production of Olive Oil, Output of Leading producing Nations, 1975 to 1986

Table II. Leading Producers of Olive Oil (Pressed Oil), 1985-6 to 1990-1

Table III. Olive Oil Trade Matrix 1986, Volume Traded

Table IV. World Exports of Olive Oil By Exporting Countries: 1980 to 1986

Table V. World Imports of Olive Oil By Country of Destination: 1970 to 1986

Table VI. Leading Importers of Olive Oil, 1984 -'89

Table VII. Prices Paid by Leading Importers of Olive Oil, 1984-'89

Table VIII. Leading Exporters of Olive Oil, 1984 -'89

Table IX. Prices Received by Leading Exporters of Olive Oil, 1984-'89

Table X. World Olive Oil Supply \& Distribution, 1985-6 to 1990-1

Table XI. U.S. Olive Oil Imports By Country of Origin: 1970 to 1986

Table XII. Breakdown of Olive Oil Collected by 'ONH' By Grade

Table XIII. Estimated Production Costs Per Hectare of Olives And Per Kilogram of Olive Oil Produced 
Table XIV. World Production of Oranges, Tangerines, and mandarins, 1970-1986

Table XV. Leading Producers of Oranges, 1985-6 to 1990-1

Table XVI. World Exports of Oranges, Tangerines, and Mandarins by Country of Origin, 19701986

Table XVII. Leading Importers of Oranges, Tangerines, and Mandarins, 1984-'89

Table XVIII. Leading Exporters of Oranges, Tangerines, and Mandarins, 1984-'89

Table XIX. Volume of U.S. Fresh Citrus Imports by Country of Origin, 1970 - 1986

Table XX. Per Capita Citrus Consumption in EEC Countries, 1982/1983 - 1985/1986 


\section{EXECUTIVE SUMMARY}

\section{OLIVE OIL}

World olive oil consumption has been flat at around 1,750,000 metric tons (MT) during the past six years. Though imports by the U.S. have increased significantly between 1984 and 1989-from 42,000 MT to 81,000 MT--and total world imports have increased from 360,000 MT to $539,000 \mathrm{MT}$, world production has remained at around $1,800,000 \mathrm{MT}$. What has occurred is that producing countries have decreased domestic consumption and/or drawn-down existing stockpiles. The top ten importing countries in 1989 imported nearly $85 \%$ of the total olive oil imported. Conversely, the top three exporting countries--Greece, Italy, and Spain--exported over $75 \%$ of all olive oil exported. The tenth largest exporter in 1989, Albania, exported less than $0.5 \%$ of total world exports.

There are very significant differences between quality and grades of olive oil and the market requires that each shipment be classified by grade and type--Super, Extra, Fine etc. and extra virgin, virgin, etc. During 1989 , the average world market price paid by importers was $\$ 2,201$ per MT. The French paid the most--\$2,718--while the USSR paid the least--\$851. The average export price received by world exporters was $\$ 2,126$ and France and Portugal were the high price suppliers while the U. S. was the least cost supplier (1989 was the first year the U.S. exported olive oil--3,000 MT).

Very little information was made available regarding the Ghaziabad Farms, but with the information available it does not appear likely nor feasible that olive oil can be exported efficiently. The estimate provided by The Mercy Fund [11] indicates a worst case production scenario of 2,400 MT and a best case scenario for the year 2000 of $13,000 \mathrm{MT}$. The best case scenario is less than $1 \%$ of total world production in 1989 . The world market for olive oil changes on average by about 100,000 MT per year and prices vary from year-to-year by approximately $\$ 270.00$ per MT. The upward trend in prices has been $\$ 160$ per MT per year. Another aspect of the situation is the unknown quality of the oil produced at the site. Both the 
prices and the demand for certain types and grades of oil varies considerably. In addition, the transportation system from the site to an exporting port--Karachi--appears difficult and perhaps not cost effective.

However, a possible scenario not mentioned in the literature provided is the feasibility of exporting to the USSR. Given the political changes of the last year, this scenario may be worth further investigation.

\section{ORANGES}

No information of any consequence was provided regarding citrus production in the Ghaziabad Farms. However, the author feels comfortable in stating that the world market for fresh oranges is very quality oriented and therefore lower quality fruit is marketed and consumed in the producing country. The limited knowledge and the world market conditions point to domestic and/or regional marketing of Ghaziabad oranges. Of particular interest would be markets in the Persian Gulf region if transport could take place across Iran. Saudi Arabia is the 8 th largest importer of oranges and the top ten importers import $75 \%$ of all imports.

Similarly to olive oil, the USSR may be the market for Ghaziabad oranges. The USSR is the fifth largest importer--many from Cuba--and between 1984 and 1989 it imported 300,000 MT per year. 


\section{Scope of Work}

The directions for the work were included in the letter dated July 15, 1991 from President Gollehon. A copy of the letter is included in the "Attachments" section. The work includes: 1.) profile of imports and exports for oranges and olive oil during the past fifteen years; 2.) supply and demand conditions; and 3.) price and production trends. Also, given the limited amount of information regarding the productive capacity and quality of product from the Ghaziabad Farms, estimate market value and potential markets.

What follows is the technical report that includes the required work.

\section{Methodology Used}

\section{Familiarization With Current Situation}

A number of publications were made available to the author. Most, if not all, were specific to the situation in Afghanistan and few were specific to the Ghaziabad Farms. All are listed in the "Reference" section. The Mercy Fund Report [11] provided the most useful information regarding the condition of the farms. However, the report is based on information gathered during 1989 and it appears that the political situation [13] has changed significantly since. Certainly the changes in the USSR during 1991 have had an impact in the situation in Afghanistan.

The assessments indicate that approximately $1,000,000$ olive trees and an equal number of citrus tree $(2,000$ hectares with 520 citrus trees per hectare) were in place in 1989 . However, the report [11] states, "...We know from direct observation and prewar records that the Khaliscontrolled sections of the three Bata Kot Farms--with about a million olive tree--can produce roughly 2000-5000 kilos of olive oil this year (1990) based on a survey made in April (early to determine crop size, hence the wide variation)." The report goes on to state, "...a reasonable olive crop, as oil could fetch (conservatively) $\$ 2-5$ million dollars per year at lowest normal world 
prices." I will assume that the first figure is a 'typo' and should read 2000-5000 MT not 20005000 kilos. Based on this assumption, then the average yield per tree is $2-5$ kilos per tree (as a point of comparison, yields in Tunisia average about 2 kilos per tree. However, in Tunisia 15\% of trees are older than 70 -years and $21 \%$ are younger than 20 -years. Peak production takes place between the 20 to 70-years of age). Assuming the Ghaziabad trees are at least 20-years old, then the 2-5 kilo yield per tree appears inflated because of the poor state of the trees.

Very little information was provided for orange production. There is a statement in [11]-"at wholesale market prices in Peshawar, the citrus crop can in peacetime be expected to yield approximately $\$ 9$ million per harvest". However, no substantiation is provided for the statement.

\section{World Import/Export Market}

Data from FAO [20] and the Foreign Agriculture Service of the USDA [23, 24] were utilized to evaluate and analyze the major importing and exporting countries in the World. The data is provided in table in the "Attachments" section and are identified in the "Table of Contents". The last year of available data is 1989 (some forecasts are provided for 1989-'90 and 1990-'91) and most of the data goes to 1975.

\section{Supply and Demand}

The supply and demand conditions are evaluated on the basis of the information provided in the "Import/Export" section and various the knowledge of the markets by the author.

\section{Price and Production}

Price data for the world olive oil importers and exporters is provided since 1984 (earlier data would have provide relatively little valuable information since the market structure has undergone significant changes). Production data for the major olive oil suppliers in from 1975. In the orange market, no prices are reported because information on Afghan orange quality, 
season, packaging, and variety is not available and orange pricing is based on this criteria. Production data for the major importers is provided from 1975.

Inconsistencies in international trade data are a 'way-of-lif e' and the various reporting sources rarely provide consistent information. With regards to oranges and olive oil, this problem is compounded because the products are marketed under various product forms and/or types. In addition, data from countries such as the USSR and Libya are invariably inaccurate.

\section{Findings}

\section{Olive Oil Production}

Figures I. and II. provide information with regards to world production from 1980 to 1986, Table I. for production from 1975 to 1986, and Table II. from 1985 -'86 to 1990 -'91. Italy is the leading producer of olive oil, but the data is unclear with regards to where to olives were produced that made the oil in Italy. Given the previous statement, total world production has been rather stable--1,800,000 MT. In fact, the highest output was during 1975 when production reached 2,041,000 MT. Olive production is cyclical or as most people in the industry refer to an 'alternate bearing' crop. in Table II, this is particularly evident in Turkish production. Another characteristic of olive oil production is the strong relationship between moisture availability during the growth of the olive on the tree and the yield in recoverable oil. In addition, the quality of the oil is very much dependent on moisture conditions during growth. Also, olive oil production variability is more pronounced in certain countries. For example, Greek production is much more stable than Italian and/or Spanish production (Figure I.).

From Figure II., it is clear that Greece, Italy, and Spain produce $78 \%$ of all the oil. However, the forecast for 1990 -'91 indicates that these three countries will only produce $64 \%$ of the world's oil. The decline in production is primarily a function of the drought conditions in those countries. 
People in the industry indicate that the future for olive oil production will continue to be flat and perhaps decline. The strong growth in the market during the 1980s was strongly correlated with U.S. imports and U.S. consumption has begun to flatten. In fact, the U.S. exported olive oil for the first time during 1989. The ability to irrigate olive groves provides those producers with significant advantages over non-irrigated groves. Not only are yields increased, but the quality of the oil is significantly increased. Therefore, countries such as Tunisia, Jordan, and Turkey that are irrigating part of their groves position them to compete more effectively the future. Table XIII. provides information regarding Tunisian olive oil cost of production (in dinars) per hectare of olive trecs and per kilogram of oil.

\section{Orange Production}

Tables XIV. and XV. provide world orange, tangerine, and mandarin production. Table XIV. does not include Brazilian production because most, if not all, of production is converted to orange juice. Brazil, however, is the largest producer or oranges. Orange production is much more diffuse than olive oil production and contrary to olive oil production, it has been increasing. From Table XIV., the top three producing countries (excluding Brazil) only represent $27 \%$ of total production. The figures and the authors knowledge of the market indicates that Mexico will become a much more significant producer of oranges and a major 'player' in both world fresh and juice markets. Mexican production has increased by $70 \%$ in six-years while world production only increased by $13 \%$ (based on five-years).

From a geographic perspective, all the major producers of olive oil are in the Mediterranean while only 7 of the 10 major orange producers are in the area. However, the world market share held by the olive oil producers is much higher than the shares held by the orange producers. 


\section{Major Exporters of Olive Oil}

Figure III. and Tables IV. \& VIII. provide the relevant data for world exports. Figure III. clearly illustrates the impressive growth between 1980 and 1986. In particular, 1983 and 1985 were heavy crop years and exports reflected the over supply. Table IV. provides export data from 1975 to 1986 and Table VIII. provides data from 1984 to 1989. From 1975 to 1989, exports have grown by $170 \%--512,000 \mathrm{MT}--$ and exports as a share of total production have increased from $9.5 \%$ to $28 \%$. These figures coupled with static production indicate that consumers in producing countries have substituted other oils for olive oil. Greece, Italy, and Spain are the leading exporters and in 1989 their exports represented $75 \%$ of total exports.

The type and quality of the oil traded in the world market varies significantly. Most importantly is the method of extraction which in turn affects the attributes of the oil. For example, the attributes for "extra virgin" oil are: color--rich chartreuse, rich chartreuse/cloudy, light chartreuse, light gold, medium gold, and pale greenish; flavor--acrid, strong/slightly acrid, rich olive/peppery, medium olive/thick, medium olive, medium olive/slightly peppery, mild/slightly peppery, mild/slightly sweet, mild/slightly acrid, bland, and bland/greasy; acidity-from $0.25 \%$ to $1.69 \%$. In addition, brands and/or labels command and maintain customer loyalty. Table XIII. gives a breakdown of the different oil produced in Tunisia.

\section{Major Importers of Olive Oil}

Figure IV. and Tables V. and VI. proved information regarding the leading importers of olive oil. Figure IV. for 1980 to 1986 illustrates the dominance of Italy as an importer. Italian imports ave increased from 85,118 MT in 1975 to 214,000 in $1989--a$ 152\% increase. The U.S. is the second largest importer and American imports increased by 277\%--from $21.486 \mathrm{MT}$ in 1975 to 81,000 MT in 1989. Total world imports increased from 202,903 MT (1975) to 539,000 MT (1989)-a $166 \%$ increase. However, the growth in the market has slowed and between 1986 and 1989 the market has been flat. These latest figures are more indicative of the future demand for olive oil and therefore the picture is for flat and perhaps reduced growth. 
Spanish imports are relatively new--significant quantities began in 1989--and are indicative of the drought as well as tree removals. Another reason is Spanish realization that the long-term future for olive oil is not very good and other uses for olive tree land will yield higher returns.

The USSR, however, is a growth market. Figure IV. indicates this (most likely the imports are from Afghanistan) as do Tables V. and VI. olive oil imports by the USSR increased a whopping 229\% between 1975 and 1989 and a significant jump occurred between 1983 and 1984.

Table III. provides a trade matrix and it is quite evident that Italy controls much of the olive oil trade--particularly with oil produced in Northern African and Middle East countries.

Table XI. gives a description of U.S. olive oil imports. Again, it is evident that Italy and to a lesser extent, Spain, dominate the U.S. oil market. The Tunisian government with the assistance of USAID conducted a study (the author was one of the authors of the study) of the feasibility of Tunisian oil entering the U.S. market and the conclusion was for the Tunisians to continue marketing through Italy. The strong brand/label recognition and loyalty makes it very difficult for other suppliers to establish a foothold in the U.S. market.

\section{Prices for Olive Oil}

Tables VII. and IX. present the prices paid and received by importers and exporters, respectively between 1984 and 1989. The price difference observed are primarily a function of quality. The French, Portuguese, and Italians are the high price countries while the USSR, Libya, and Spain are the low price countries. The Spanish are new importers with relatively low volume of imports, but the volume and prices received by Spanish exporters are significantly higher than import quantities and import prices. This development indicates a substitution within Spanish consumption for lower quality oil for higher priced oil. For the years 1985 through 1988, Spanish import versus export price was over $\$ 1,000$ per MT! 
The world market structure is such that either Italy and/or Spain control a significant component of olive oil distribution. Also, Tunisian olive oil has developed into a higher quality oil and it provides a potential model for Afghan oil development. The important question is whether the volume of production in Afghanistan can sustain a period of product development.

The average price for world olive oil imports over the past six years has been $\$ 1,503$ per MT while the average world export price has been $\$ 1,667--a$ \$164 dollar differential. This differential is a result of various factors such a transaction terms, oil quality/volume, price discounts to move product, and supply/demand condition during a marketing season. For the major exporters, the relationship between export price and export quantity is slightly negative--a correlation coefficient of -0.16 while the relationship between import price and import quantities is positive and equal to 0.14 . Neither correlation coefficient is high which indicates relatively little relationship between prices and quantities. this would be expected given the aggregate nature of the data--i.e. all types of oils are lumped into one number.

Table $X$. provides recent data regarding the distribution of olive oil production and trade. It is apparent that world consumption is flat, but more importantly are the statistics regarding year-end stocks. The volume of stocks-- $660,000 \mathrm{MT}--$ can be used to combat any new entrants into the market and the apparent market practice is to have enough olive oil to meet next years demands in the world market.

\section{Major Imports of Oranges}

Table XVII. provides figures for the major importers of oranges, tangerines, and mandarins between 1984 and 1989. With the exception of Saudi Arabia, all the major importers are Europeans or Pacific Basin countries. Also, the top ten major importers only import about $25 \%$ of total world imports--very different from the olive oil market. The phytosanitary requirements for orange imports are quite restrictive and elaborate testing and/or inspection is required before product can enter markets. 


\section{Major Exporters of Oranges}

Table XVIII. lists the relevant data for the major exporters of oranges. The top ten exporters export $80 \%$ of all oranges and the trend is for greater concentration. Spain and Mexico have the capacity, capital, climate, and know-how to increase exports significantly. In addition, seven of the top ten exporters are in the Mediterranean region. Also, countries such as Zimbabwe have developed their orange industry and within the next ten years will be exporting significant quantities of oranges.

Given the limited information about orange production in the Ghaziabad Farms and the potential production in other more developed countries, Afghani oranges do not appear to be able to establish a presence in the world fresh orange market. The country should concentrate in exporting to its immediate neighbors and again the USSR appears to be the best market. This would be particularly true if the Cubans begin sending their oranges to western countries rather than the USSR and Eastern block countries. In fact, Afghanistan may be in a relatively good position to enter and expand orange exports within the region. Table XIX. lists the leading importing countries during 1975 to 1986 and Table XX. provides per capita consumption figures for the major European countries.

\section{Market Value of Ghaziabad Farms' Crop Value}

The olive oil crop I would estimate to be in the neighborhood of $\$ 2,000,000$ for the first productive year. This is based on an output of $2,000 \mathrm{MT}$ and a price of $\$ 1,000$ per MT. This figures are very speculative because of the unknown quality of the product. Export prices have been increasing at the rate of approximately $\$ 160$ per MT and therefore the expected price in the year 2000 would be nearly $\$ 4,000 \mathrm{MT}$. If output increases to $15,000 \mathrm{MT}$, then the value of the crop would be $\$ 60,000,000$ in the year 2000 . These are very generous figures, particularly the rate of production. Output would need to increase nearly seven fold over a ten year period. 
The figure mentioned in [11] of $\$ 10,000$ per MT for the 1990 -' 91 season is too high and even if this price was received in the market it could not be sustained. There is no indication in historical price series of sustained high prices.

For the orange market, the information provided does not allow for any estimate regarding the value of the crop.

\section{Conclusions and Recommendations}

Given the above, it should first be noted that all the information regarding the Ghaziabad Farms was considered to be imprecise--particularly the orange data. Also, the political situation in Afghanistan has changed significantly since most of the information was gathered.

Therefore, the structural conditions may currently be such that relations and/or trade with the USSR may be more plausible. This would certainly be a very good outcome for both olive oil and orange exports to the USSR. However, the currency requirements may be limiting, but barter trade may still be feasible.

The transportation system to major exporting ports appears to be limiting and the establishment of olive oil processing plants may also be limiting. Large questions remain regarding the condition of the irrigation systems for the farms as well as the machinery requirements to reach output levels of 15,000 MT of olive oil. At 15,000 MT of output the trees-1,000,000--would need to yield 15 kilograms per tree. These yield are very high and therefore doubtful!

World olive oil consumption in flat and at least one major producer--Spain--appears to be scaling back on production. The volume of year-end stocks are generally sufficient to meet the next years demand and therefore price volatility is not expected to change appreciably from historical norms. Prices have been increasing at the rate of $\$ 160$ per MT. 
A careful and detailed study needs to be conducted to look at: 1.) the quality of the oil that can be produced, 2.) the cost of increasing yields five-fold, 3.) the mode of transporting the product, 4.) the organizational structure for managing the farms, 5.) alternatives for other uses of capital and that potential return vis-a-vis olive oil production, and 6.) the opportunity costs of leaving the groves in dis-repair.

The author cannot make any recommendations regarding the orange groves because the information is too limited. 


\section{REFERENCES}

1.) Bakley, Robert, Correspondence and Summary of Ghaziabad Farms Project, American Embassy, Islamabad, Pakistan. March 20, 1991

3.) Etienne, G., "Some Observations on the Reconstruction and Development of Afghanistan With Emphasis on the Rural Economy", Discussion paper No. 1, Seminar on the Potential for Recovery in Afghanistan and the Role of International Assistance, OPERATION SALAM, Geneva, Switzerland. May 5-7, 1989.

3.) Fange, A. "The Agricultural Survey of Afghanistan: First Report on the Agricultural Survey of Afghanistan national trends and Averages", Swedish Committee for Afghanistan (SCA), May 1988

4.) Food Merchants Advocate, "Olive Oil is here now! Something good that's good for you". May 1990.

5.) Georgetown Venture/Trading Company, Inc., "The U.S. Market for Olive Oil: Strategies for Expanding Tunisian Market Penetration", 3075 Canal Towpath, Washington, DC 2007. May 4, 1988

6.) Ithaca International Limited, Export Commodity Study Citrus, Tunisia Agricultural Policy Implementation Project, USAID/Ministry of Agriculture, Project No. 664-0343, 707 Cayuga Heights Road, Ithaca, NY. March 1989.

7.) Ithaca International Limited, Export Commodity Study Olive Oil, Part A, Tunisia Agricultural Policy Implementation Project, USAID/Ministry of Agriculture, Project No. 664-0343, 707 Cayuga Heights Road, Ithaca, NY. October 1988.

8.) Ithaca International Limited, Export Commodity Study Olive Oil, Part B, Tunisia Agricultural Policy Implementation Project, USAID/Ministry of Agriculture, Project No. 664-0343, 707 Cayuga Heights Road, Ithaca, NY. October 1988.

9.) Lambert, M. "Olive Oil Stockpiles Illustrate Europe's Farm Dilemma", United States Department of Agriculture, Economic Research Service, Farmline, October 1987.

10.) Lewis, Jerry, "Afghanistan Small Farmer Production Credit Funded Through Monetization of PL-480 Edible Oil", Agricultural Cooperative Development International, Washington, DC. August 18, 1989.

11.) Mercy Fund, "Olive Industry Resuscitation in Nagarhar Province Afghanistan", A Proposal and Annexes, Khattak House, Old Bara Road, University Town, Peshawar Pakistan. November 1, 1990.

12.) Nathan, Robert, R. \& Associates, Inc., and Loius Berger International, Inc., "Profile of Private Sector Cross-Border trade Between Afghanistan and Pakistan", Washington, DC. August 1989.

13.) New York Times, "Despite Civil War, Kabul and Afghan Rebels Hold Their Fire in Some Areas". October 13, 1991.

14.) -----, "Afghan Hopes for New Aid". August 31, 1991. 
15.) -----, "Mediterranean Gold: An Olive Oil Invasion". June 7, 1989

16.) -----, "Marketing Olive Oil That's Light on the Olives: Filippo Berio and Bertolli try to woo Americans who like their oil mild". April 16, 1989.

17.) -.--- "In the Pantheon of Fine Olive Oils, the Top". April 13, 1988.

18.) Roy, O. "Afghanistan: The Social Aspects of Recovery in a Fragmented Society", Discussion paper No. 4, Seminar on the Potential for Recovery in Afghanistan and the Role of International Assistance, OPERATION SALAM, Geneva, Switzerland. May 5-7, 1989.

19.) Sediq, M. and Theisen, A. "Agricultural Reconstruction and Rehabitation in Afghanistan", VITA News, July 1989.

20.) United Nations, FAO Yearbook: Trade Commerce, Food and Agriculture organization of the United Nations, FAO Statistics Series No. 91. Various Issues

21.) United Nations, First Consolidated Report, Office of the United Nations Co-Ordinator for Humanitarian and Economic Assistance Programmes Relating to Afghanistan, Geneva, Switzerland. September 1988.

22.) United States Agency for International Development, Afghanistan: CY 1989 Food Aid Operational Plan", Office of the AID Representative for Afghanistan, Islamabad, Pakistan. April 1989.

23.) United States Department of Agriculture, Foreign Agricultural Service, Foreign Agriculture, 1990-91. August 1991.

24.) ---- Foreign Agriculture. 1989. October 1989.

25.) Wall Street Journal, "Olive Oil Health Claims in Ads Spark FTC Charges Against Major Importer". September 6, 1991.

26.) -----"Afghan Resistance in Feeling Abandoned: Cold War's End Finds Rebel Groups Turning on Each Other". September 6, 1991.

27.) -----"Frontier Economy: To the Feuds, Malaise And Guns of Pakistan Comes the Free Market". July $31,1991$.

28.) -----"Corn, Olive Oils Help Lower Cholesterol At Similar Rates, Diet Study Shows". May 9, 1990 
50 F Street. N.W. • suite 900 - Washington. D.C. 20001

Tslephone: (202) 638-4661

Cable: AGCODEV

Telex: 160923

Fax: (202) 626-8726

Carinet (Dialcom): 157: GCD 0016

July 15,1991

Enrique Figueroa

346 Warren Hall

Cornell University

Ithaca, NY 14853-7801

Dear Dr. Figueroa:

This is your letter of assignment as Agricultural Economist to work for ACDI in the United States. This assignment is intended to provide information on the technical and economic feasibility of reorganizing a group of large collective farms, the Ghaziabad farms, in Afghanistan into a private venture. In order to pursue this possibility, an analysis of the farms must be conducted to determine their commercial and agricultural potential and feasibility of organizing them as cooperatives or other forms of private businesses. Your work will support the overall analysis and focus on the international market aspects of the crops grown on the Ghaziabad farms. You work will be conducted in the U.S. While on this assignment you are to report to Mr. Jerry Lewis, Vice President, Asia, Near East and the Pacific.

A. Your scope of work is as follows:

1. Prepare an overview of the international olive and orange markets, identifying major importers and exports, and assessing potential markets for Afghan olive and orange produce. This assessment will be based on the analysis of relevant import/export, supply/demand, price and production trends over the past 15 years. Realizing that little information exists concerning the quality and past marketing success of Afghan olives, this analysis will by necessity make a number of assumptions.

2. Given the available information, estimate the market value of Ghaziabad Farms' crop ont an annual basis and identify potential markets for output using conservative output forecasts.

3. Prepare a technical report of your activities. See attached sample of final report format.

4. Other duties as may be assigned by Jerry Lewis which are consistent with the overall scope of this assignment. 
B. Your assignment is subject to the following:

1. Term of Assignment: To begin on or about July 15, 1991, for approximately ten (10) work days. This can be extended upon mutual agreement. While on this assignment a five day work week is authorized. The assignment is scheduled to be completed before August 31, 1991.

2. Compensation: Your fee will be $\$ 278$ per day for days actually worked. No travel days are authorized.

3. Reports: The following reports are required in order to fully pay you the fee stipulated in Item B-2 above:

a. Time and Attendance Forms: Copies are attached to this letter of assignment. You should complete these showing the days and number of hours up to eight worked. Timesheets must be received by the Finance department by the 8th and 22nd of each month in order to be paid on our scheduled paydays, which are on the 15th and the 30th.

b. Technical Report: As indicated in the scope of work.

Please sign and retum to ACDI the original and one copy of this letter indicating acceptance of this assignment on the above terms.

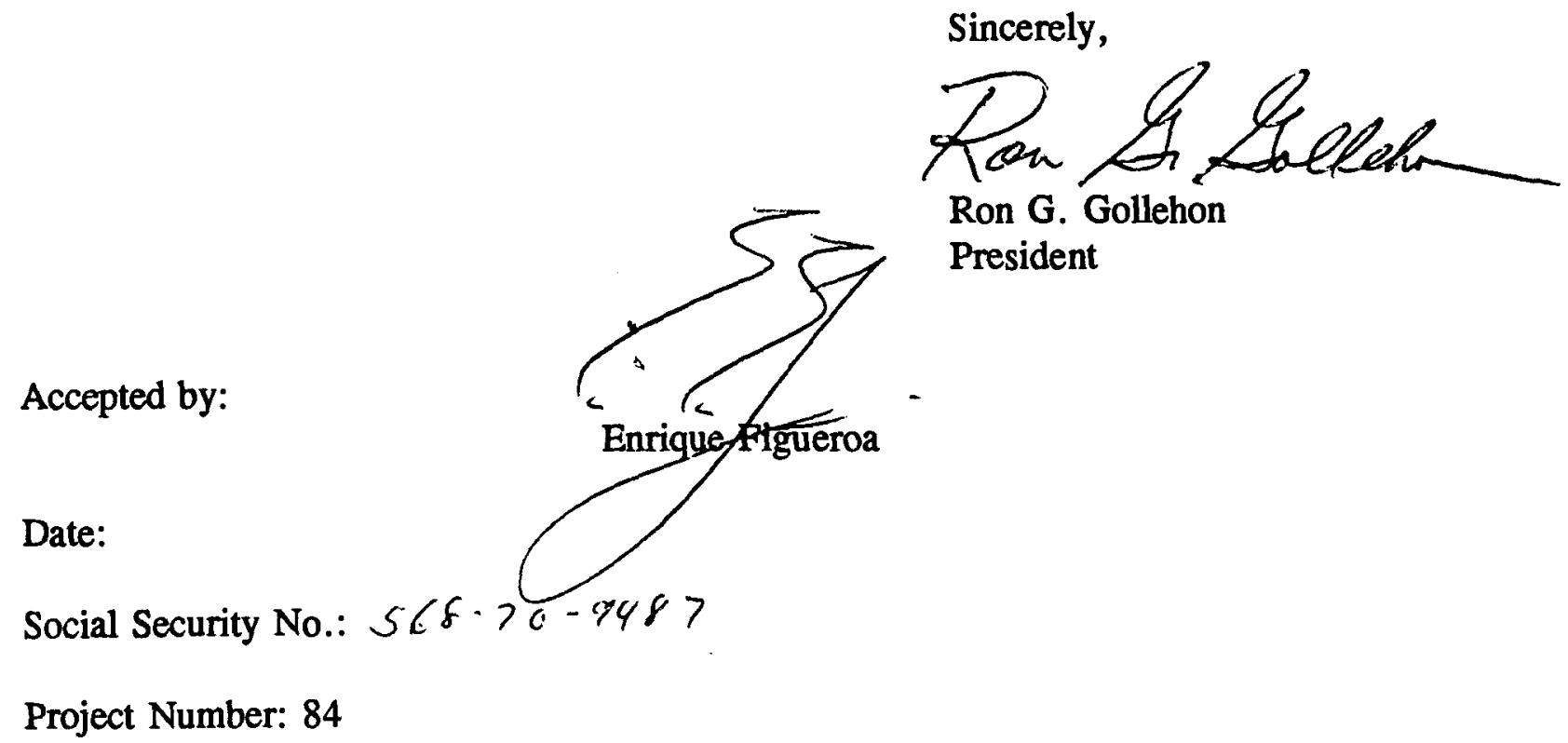




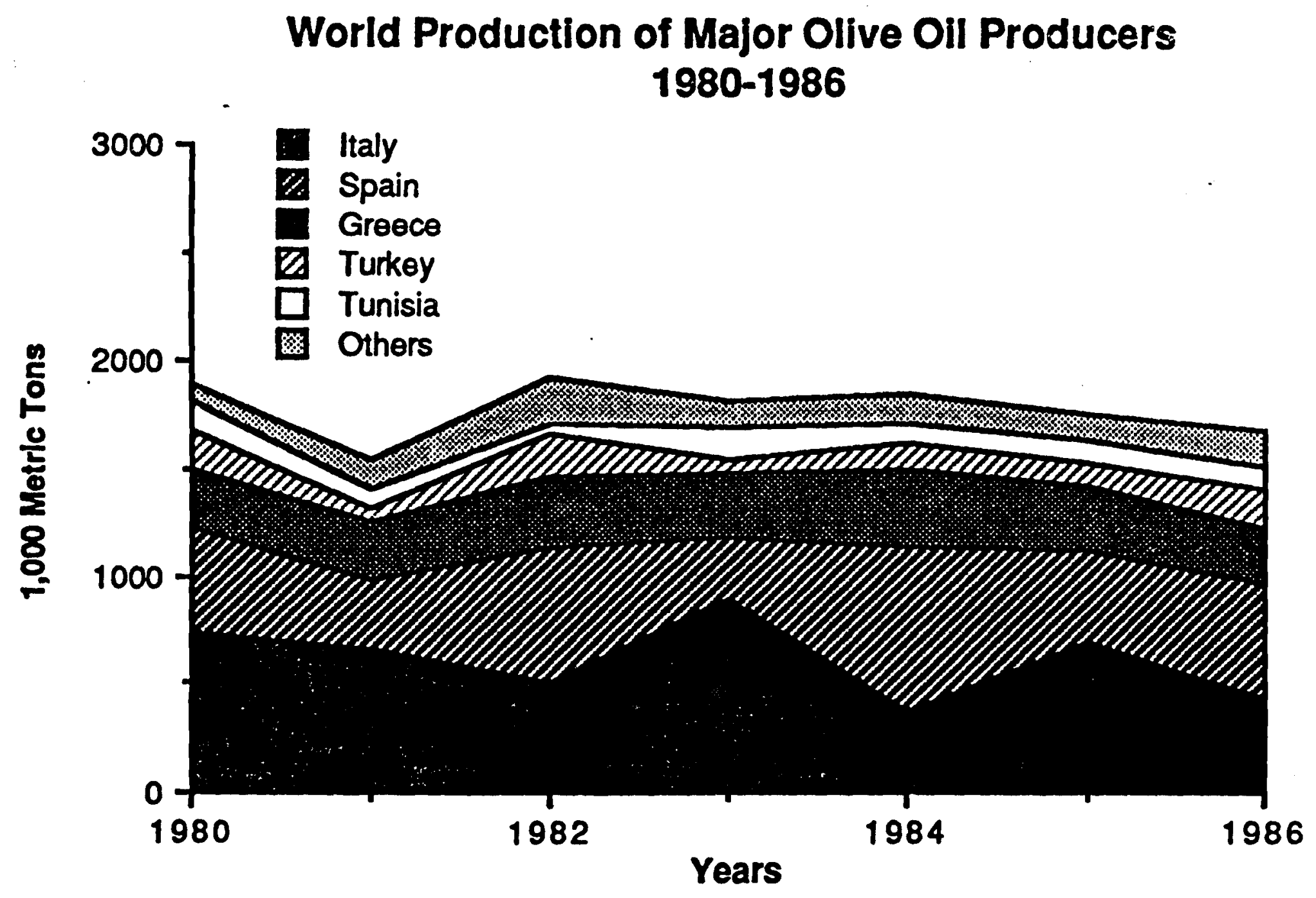




\section{Average Country Shares of World Olive Oil Production 1981 to 1986}

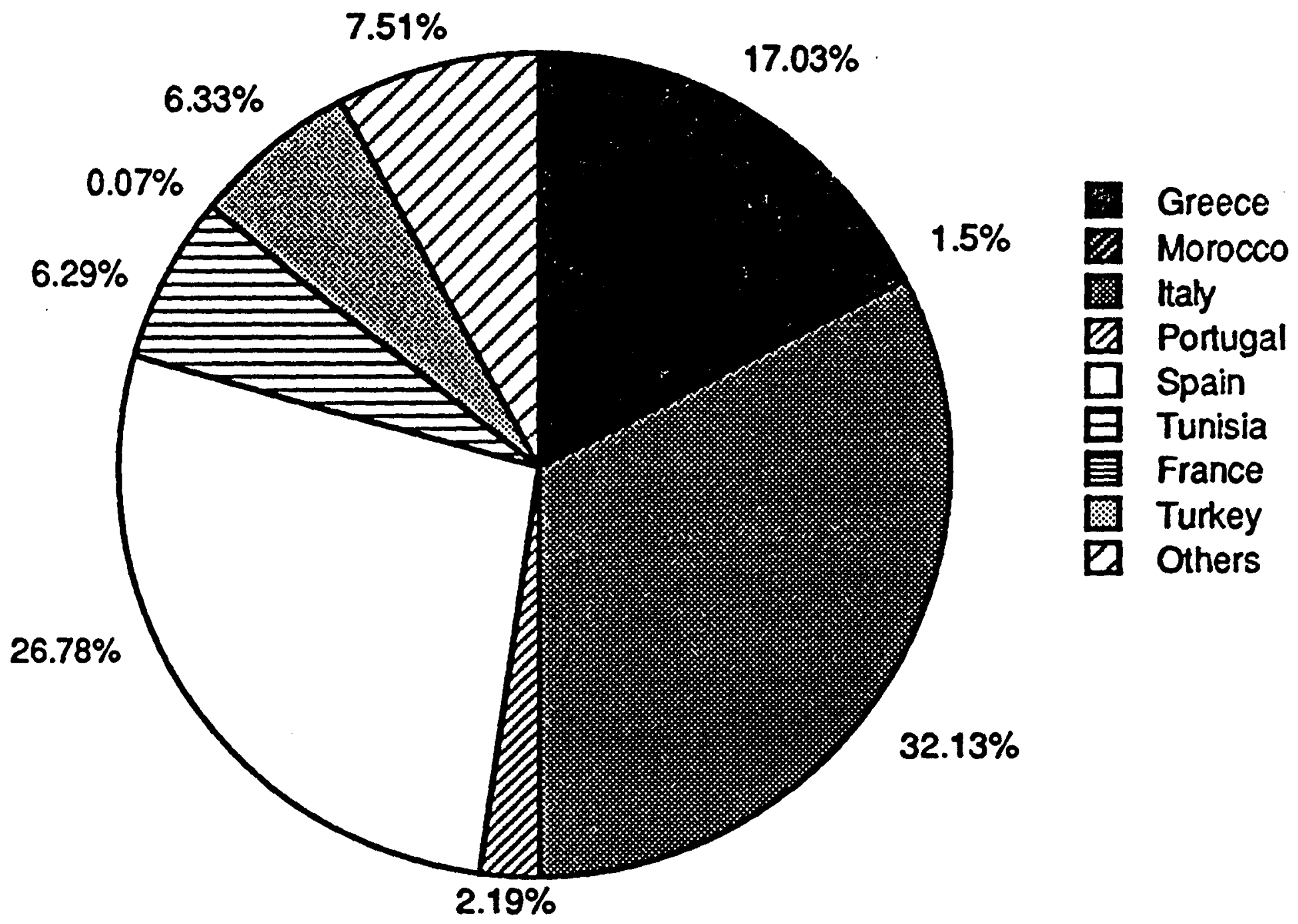

SOURCE: REFERENCE \# 8 


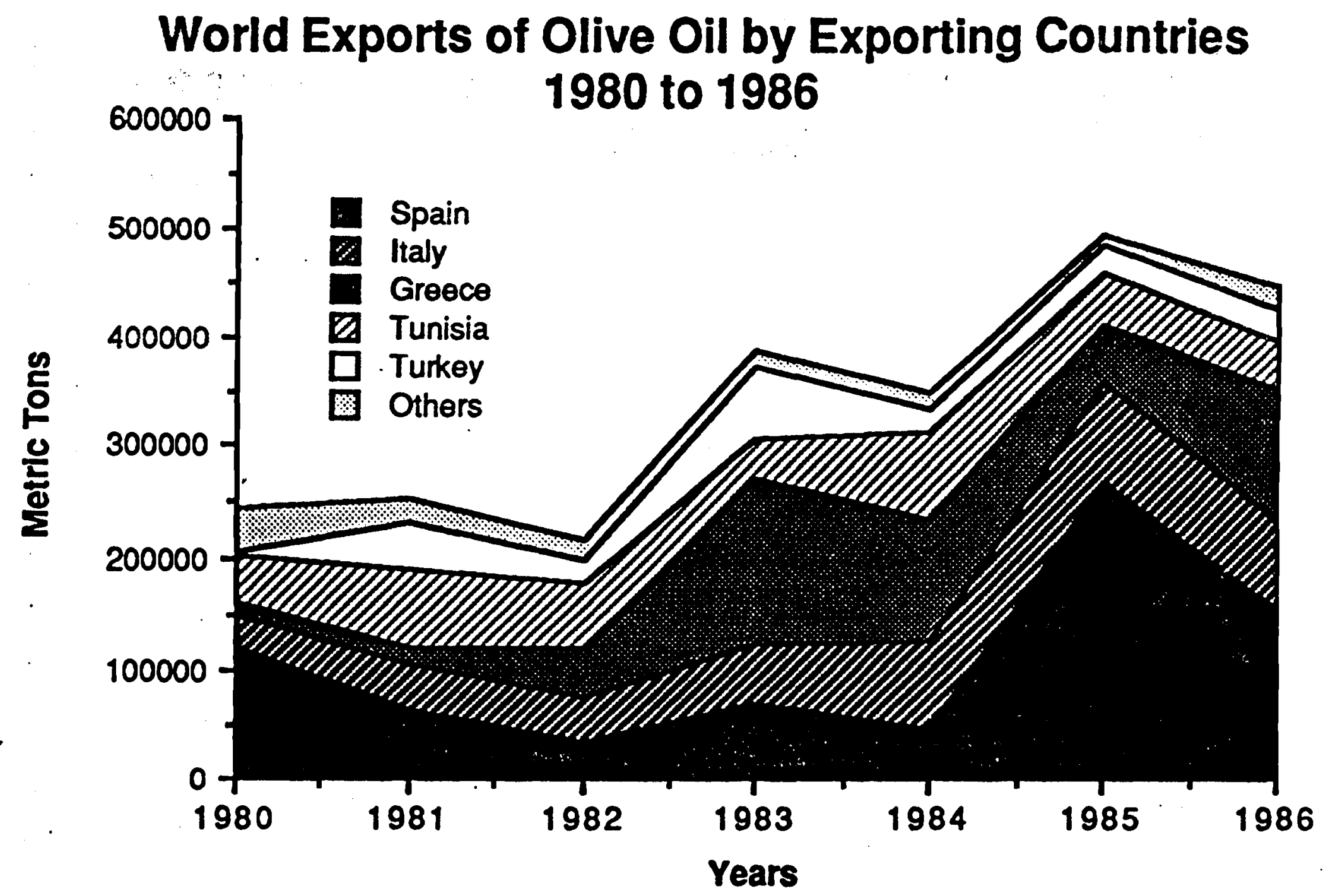


WORLD PRODUCTION OF OLNE OIL

OUTPUT OF LEADING PRODUCING NATIONS - 1975 TO 1986

\begin{tabular}{|c|c|c|c|c|c|c|}
\hline \multicolumn{7}{|c|}{ (1000 metric tons) } \\
\hline Production & 1975 & 1976 & 1977 & 1978 & 1979 & 1980 \\
\hline $\begin{array}{l}\text { Greece } \\
\text { Italy } \\
\text { Morocco } \\
\text { Portugal } \\
\text { Spain } \\
\text { Tunisia } \\
\text { France } \\
\text { Turkey } \\
\text { Others }\end{array}$ & $\begin{array}{r}288 \\
606 \\
44 \\
58 \\
509 \\
196 \\
2 \\
110 \\
228\end{array}$ & $\begin{array}{r}251 \\
325 \\
41 \\
43 \\
442 \\
102 \\
2 \\
201 \\
109\end{array}$ & $\begin{array}{r}309 \\
739 \\
32 \\
40 \\
359 \\
132 \\
2 \\
81 \\
1\end{array}$ & $\begin{array}{r}262 \\
454 \\
24 \\
47 \\
548 \\
87 \\
2 \\
201 \\
171\end{array}$ & $\begin{array}{r}228 \\
513 \\
39 \\
55 \\
483 \\
94 \\
2 \\
84 \\
119\end{array}$ & $\begin{array}{r}281 \\
730 \\
28 \\
62 \\
488 \\
145 \\
2 \\
185 \\
69\end{array}$ \\
\hline \multirow[t]{2}{*}{ World } & 2041 & 1516 & 1589 & 1796 & 1617 & 1990 \\
\hline & 1981 & 1982 & 1983 & 1984 & 1985 & 1986 \\
\hline $\begin{array}{l}\text { Greece } \\
\text { Italy } \\
\text { Morocco } \\
\text { Portugal } \\
\text { Spain } \\
\text { Tunisia } \\
\text { France } \\
\text { Turkey } \\
\text { Others }\end{array}$ & $\begin{array}{r}272 \\
655 \\
20 \\
26 \\
322 \\
85 \\
2 \\
74 \\
131\end{array}$ & $\begin{array}{r}351 \\
510 \\
43 \\
58 \\
615 \\
58 \\
0 \\
185 \\
217\end{array}$ & $\begin{array}{r}317 \\
885 \\
24 \\
13 \\
288 \\
155 \\
2 \\
49 \\
127\end{array}$ & $\begin{array}{r}360 \\
370 \\
30 \\
57 \\
763 \\
95 \\
2 \\
122 \\
136\end{array}$ & $\begin{array}{r}310 \\
690 \\
31 \\
31 \\
42 \\
429 \\
105 \\
11 \\
98 \\
125\end{array}$ & $\begin{array}{r}267 \\
430 \\
35 \\
46 \\
534 \\
120 \\
1 \\
170 \\
167\end{array}$ \\
\hline World & 1587 & 2037 & 1860 & 1935 & 1831 & 1770 \\
\hline
\end{tabular}

Source: FAO Production Yearbook.

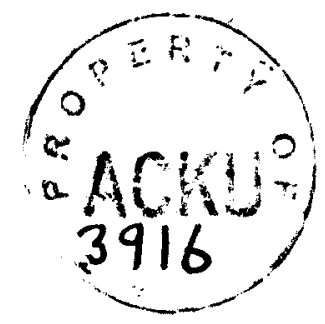


IEADING PRODUCERS OF OIIVE OIL (PRESSED OII), 1985-6 to 1990-1.

\begin{tabular}{l|c|cccc} 
& & CROP & YEAR & \\
\hline
\end{tabular}

Figures for $1988-9$ are preliminary, figures for 1989-90 \& 1990-1 are forecasts. Years are from November 1, to October 31. USDA, FAS, Oil World 
OLIVE OIL TRADE MATRIX 1986, VOLUME ${ }^{\mathrm{a}}$ TRADED (MT)

\begin{tabular}{|c|c|c|c|c|c|c|c|c|c|c|c|c|c|}
\hline \multirow[b]{2}{*}{$\begin{array}{c}\text { Country of } \\
\text { Origin }\end{array}$} & \multicolumn{11}{|c|}{ Country of Destination } & \multirow[b]{2}{*}{ Other } & \multirow{2}{*}{$\begin{array}{c}\text { Total } \\
\text { Exports }\end{array}$} \\
\hline & Italy & Greece & Spain & France & UK & & & Libya & USSR & USA & Canada & & \\
\hline Italy & - & 5 & 1,627 & 11,753 & 2,432 & 0 & & .093 & 6,520 & 35,107 & 1,871 & 13,002 & 80,410 \\
\hline Greece & 128,281 & - & 0 & 238 & 471 & 0 & & 0 & 2,329 & 903 & 367 & \multicolumn{2}{|c|}{$-114,119$} \\
\hline Spain & 72,514 & 0 & - & 14,546 & 34,336 & 0 & & 351 & 3,002 & 10,481 & 1,237 & 17,833 & 157,300 \\
\hline France & 7,522 & 0 & 0 & - & 454 & 0 & & 0 & 0 & 241 & 32 & - & 8,249 \\
\hline United Kingdon & m 12,210 & 0 & 0 & 0 & - & 0 & & 0 & 0 & 4 & 0 & 8,348 & 20,652 \\
\hline Tunisia & 20,351 & 0 & 0 & 712 & 0 & - & & 0 & 7,000 & 1,331 & 17 & 15,037 & 44,448 \\
\hline Libya & 0 & 0 & 0 & 0 & 0 & 0 & & - & 0 & 0 & 0 & 0 & 0 \\
\hline USSR & 0 & 0 & 0 & 0 & 0 & 0 & & 0 & - & 0 & 0 & 0 & 0 \\
\hline USA & 0 & 0 & 0 & 0 & 0 & 0 & & 0 & 0 & - & 0 & 0 & 0 \\
\hline Canada & 0 & 0 & 0 & 0 & 0 & 0 & & 0 & 0 & 0 & - & 0 & 0 \\
\hline Other & 0 & 1 & 2,845 & 396 & 2,105 & 0 & 20 & .556 & 9,196 & 4,147 & 591 & - & 54,824 \\
\hline $\begin{array}{l}\text { Total } \\
\text { Imports }\end{array}$ & $231,427^{*}$ & 6 & 4,472 & 27,645 & 39,798 & 0 & 32 &, 000 & 28,047 & 52,214 & 4,115 & 88,583 & - \\
\hline
\end{tabular}

a All olive oil (Virgin, Lampante, Refined, Untreated)

Sources: EEC Countries - Import Data from Eurostat Trade Statistics
Tunisia - L'Office National del'Huile (Tunisia)
USA - Foreign Agricultural Trade Statistics
Canada - Agriculture Canada
Total Imports - FAO Trade Year Book
Libya, USSR - Eurostat Export Data

"FAO figures less than total for individual countries. 
WORLD EXPORTS OF OUVE OIL

BY COUNTRY OF ORIGIN - 1970 TO 1986 (metric tons)

\begin{tabular}{|c|c|c|c|c|c|c|c|c|c|}
\hline Country & 1970 & 1975 & 1980 & 1981 & 1982 & 1983 & 1984 & 1985 & 1986 \\
\hline \multicolumn{10}{|l|}{ EUROPE } \\
\hline Spain & 178862 & 49179 & 122326 & 63574 & 34193 & 72034 & 46416 & 269578 & 157300 \\
\hline $\begin{array}{l}\text { Italy } \\
\text { Greece } \\
\text { Portugal } \\
\text { France } \\
\text { U.K. } \\
\text { Other }\end{array}$ & $\begin{array}{r}15503 \\
12296 \\
11663 \\
3522 \\
112 \\
559\end{array}$ & $\begin{array}{r}12264 \\
32126 \\
2880 \\
3282 \\
201 \\
4739\end{array}$ & $\begin{array}{r}28635 \\
11901 \\
3107 \\
21553 \\
742 \\
1110\end{array}$ & $\begin{array}{r}42561 \\
14975 \\
3490 \\
12559 \\
682 \\
943\end{array}$ & $\begin{array}{r}42551 \\
44922 \\
3484 \\
19306 \\
481 \\
541\end{array}$ & $\begin{array}{r}51506 \\
147520 \\
3539 \\
20560 \\
582 \\
719\end{array}$ & $\begin{array}{r}81513 \\
108417 \\
5618 \\
3219 \\
701 \\
565\end{array}$ & $\begin{array}{r}87911 \\
53569 \\
4040 \\
5804 \\
587 \\
592\end{array}$ & $\begin{array}{r}80410 \\
114119 \\
8698 \\
5087 \\
20652 \\
8794\end{array}$ \\
\hline Total & 222517 & 104671 & 189374 & 138784 & 145388 & 296460 & 246449 & 422081 & 395060 \\
\hline \multicolumn{10}{|l|}{ AFRICA } \\
\hline $\begin{array}{l}\text { Tunisia } \\
\text { Other }\end{array}$ & $\begin{array}{l}24994 \\
10583\end{array}$ & $\begin{array}{l}42240 \\
16687\end{array}$ & $\begin{array}{l}48721 \\
12363\end{array}$ & $\begin{array}{r}70365 \\
570\end{array}$ & $\begin{array}{r}62146 \\
596\end{array}$ & $\begin{array}{r}36117 \\
1731\end{array}$ & $\begin{array}{r}70674 \\
7072\end{array}$ & $\begin{array}{r}50921 \\
336\end{array}$ & $\begin{array}{r}44448 \\
206\end{array}$ \\
\hline Total & 35577 & 58927 & 61084 & 71205 & 62742 & 37848 & 77746 & 51257 & 44654 \\
\hline \multicolumn{10}{|l|}{ ASIA } \\
\hline $\begin{array}{l}\text { Turkey } \\
\text { Gaza Strip } \\
\text { Other }\end{array}$ & $\begin{array}{r}310 \\
\text { N/A } \\
1429\end{array}$ & $\begin{array}{r}9342 \\
\text { N/A } \\
7229\end{array}$ & $\begin{array}{l}3339 \\
6200 \\
1737\end{array}$ & $\begin{array}{r}43447 \\
5000 \\
3781\end{array}$ & $\begin{array}{r}20556 \\
7156 \\
2314\end{array}$ & $\begin{array}{r}63747 \\
4551 \\
1855\end{array}$ & $\begin{array}{r}20788 \\
5165 \\
2166\end{array}$ & $\begin{array}{r}26658 \\
3000 \\
537\end{array}$ & $\begin{array}{r}28825 \\
5000 \\
3374\end{array}$ \\
\hline S. AMERICA & 3450 & 9267 & 9752 & 8195 & 6336 & 6388 & 4896 & 6072 & 3338 \\
\hline OTHER & 1 & 1 & 3 & 3 & 12 & 12 & - & 3 & 9 \\
\hline TOTAL & 263284 & 189437 & 271488 & 270414 & 241824 & 410861 & 357210 & 504902 & 480002 \\
\hline
\end{tabular}

Source: FAO Trade Year Book. Various Years 
TABLE $V$.

WORLD IMPORTS OF OUVE OIL

BY COUNTRY OF DESTINATION - 1970 TO 1986 (metric tons)

\begin{tabular}{|c|c|c|c|c|c|c|c|c|c|}
\hline Country & 1970 & 1975 & 1980 & 1981 & 1982 & 1983 & 1984 & 1985 & 1986 \\
\hline \multicolumn{10}{|l|}{ EUROPE } \\
\hline $\begin{array}{l}\text { Italy } \\
\text { France } \\
\text { W. Germany } \\
\text { U.K. } \\
\text { Other }\end{array}$ & $\begin{array}{r}132796 \\
14956 \\
3203 \\
2889 \\
9855\end{array}$ & $\begin{array}{r}85118 \\
21802 \\
3358 \\
2636 \\
13991\end{array}$ & $\begin{array}{r}131443 \\
61366 \\
3531 \\
2596 \\
10393\end{array}$ & $\begin{array}{r}57901 \\
33040 \\
3450 \\
2567 \\
11466\end{array}$ & $\begin{array}{r}75294 \\
27071 \\
3184 \\
2719 \\
-27681\end{array}$ & $\begin{array}{r}204594 \\
29544 \\
4280 \\
3511 \\
11324\end{array}$ & $\begin{array}{r}165394 \\
24534 \\
4139 \\
3519 \\
11371\end{array}$ & $\begin{array}{r}253419 \\
30017 \\
5777 \\
3753 \\
14303\end{array}$ & $\begin{array}{r}231427 \\
27645 \\
6274 \\
39798 \\
24753\end{array}$ \\
\hline Tolal & 163799 & 126905 & 209329 & 108424 & 135949 & 253263 & 208957 & 307269 & 329897 \\
\hline \multicolumn{10}{|l|}{ AFRICA } \\
\hline $\begin{array}{l}\text { Libya } \\
\text { Other }\end{array}$ & $\begin{array}{r}18627 \\
8290\end{array}$ & $\begin{array}{r}21288 \\
2005\end{array}$ & $\begin{array}{r}61395 \\
3414\end{array}$ & $\begin{array}{r}56013 \\
3744\end{array}$ & $\begin{array}{r}46944 \\
2418\end{array}$ & $\begin{array}{r}62003 \\
6225\end{array}$ & $\begin{array}{r}30000 \\
3651\end{array}$ & $\begin{array}{r}28000 \\
4569\end{array}$ & $\begin{array}{r}32000 \\
4983\end{array}$ \\
\hline Total & 26917 & 23293 & 64809 & 59757 & 49362 & 68225 & 33651 & 32569 & 36983 \\
\hline \multicolumn{10}{|l|}{ ASIA } \\
\hline $\begin{array}{l}\text { Turkey } \\
\text { Jordan } \\
\text { Other }\end{array}$ & $\begin{array}{r}\text { N/A } \\
90 \\
?\end{array}$ & $\begin{array}{r}N / A \\
206 \\
?\end{array}$ & $\begin{array}{r}\text { N/A } \\
8513 \\
?\end{array}$ & $\begin{array}{r}\text { N/A } \\
2800 \\
?\end{array}$ & $\begin{array}{r}\text { N/A } \\
8983 \\
?\end{array}$ & $\begin{array}{r}\text { N/A } \\
4642 \\
?\end{array}$ & $\begin{array}{r}2797 \\
6947 \\
21181\end{array}$ & $\begin{array}{r}31513 \\
6000 \\
26270\end{array}$ & $\begin{array}{r}12810 \\
7420 \\
24794\end{array}$ \\
\hline \multicolumn{10}{|l|}{ N. AMERICA } \\
\hline $\begin{array}{l}\text { USA } \\
\text { Other }\end{array}$ & $\begin{array}{r}28507 \\
3581\end{array}$ & $\begin{array}{r}21486 \\
3059\end{array}$ & $\begin{array}{r}25827 \\
6215\end{array}$ & $\begin{array}{r}27725 \\
4139\end{array}$ & $\begin{array}{r}29140 \\
5309\end{array}$ & $\begin{array}{r}33039 \\
-\quad 5230\end{array}$ & $\begin{array}{r}41637 \\
6480\end{array}$ & $\begin{array}{r}44496 \\
6049\end{array}$ & $\begin{array}{l}52160 \\
-5157\end{array}$ \\
\hline Total & 32088 & 24545 & 32042 & 31864 & 34449 & 38269 & 48117 & 50545 & 57317 \\
\hline \multicolumn{10}{|l|}{ S. AMERICA } \\
\hline $\begin{array}{l}\text { Brazil } \\
\text { Other }\end{array}$ & $\begin{array}{r}13229 \\
1316\end{array}$ & $\begin{array}{l}9743 \\
1090\end{array}$ & $\begin{array}{l}8012 \\
2133\end{array}$ & $\begin{array}{r}10797 \\
1936\end{array}$ & $\begin{array}{l}9575 \\
1210\end{array}$ & $\begin{array}{r}10472 \\
925\end{array}$ & $\begin{array}{r}8160 \\
839\end{array}$ & $\begin{array}{l}9765 \\
1593\end{array}$ & $\begin{array}{r}11000 \\
1436\end{array}$ \\
\hline Total & 14545 & 10833 & 10145 & 12733 & 10785 & 11397 & 8999 & 11358 & 12436 \\
\hline USSR & 8500 & 5157 & 11570 & 15184 & $7 7 \longdiv { 4 9 }$ & 15036 & 21452 & 26023 & 28047 \\
\hline OCEANA & 5511 & 3907 & 6376 & 6380 & 6684 & 7158 & 8377 & 1834 & 8054 \\
\hline TOTAL & 225616 & 202903 & 363078 & 261235 & 272790 & 417936 & 360478 & 493381 & 517758 \\
\hline
\end{tabular}


TABLE VI.

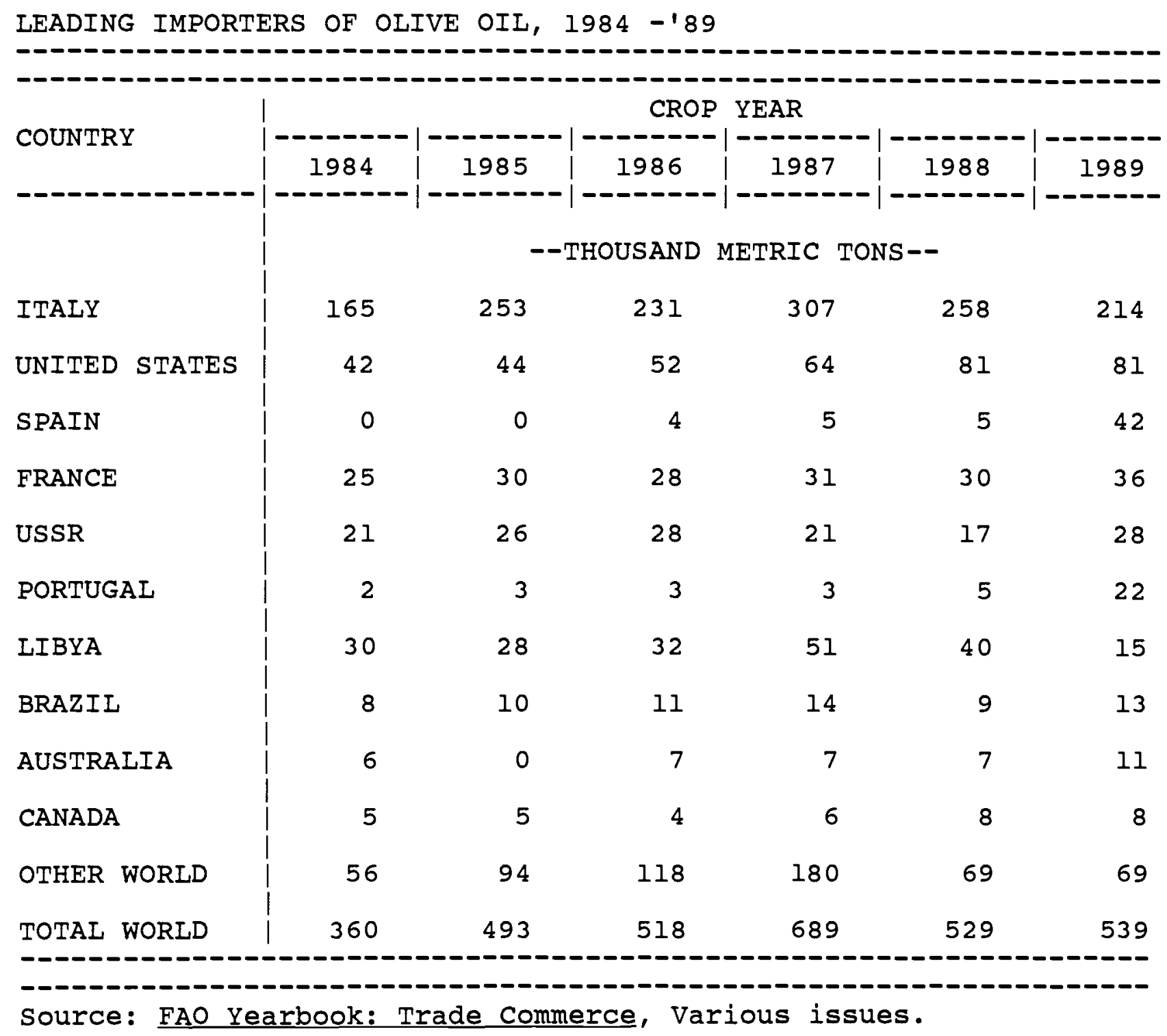


PRICES PAID BY LEADING IMPORTERS OF OLIVE OIL, $1984-189$

\begin{tabular}{|c|c|c|c|c|c|c|}
\hline \multirow{2}{*}{ COUNTRY } & \multicolumn{6}{|c|}{ CROP YEAR } \\
\hline & 1984 & 1985 & 1986 & 1987 & 1988 & 1989 \\
\hline & & $--U \cdot S \cdot$ & OLLARS F & METRIC & TONS-- & \\
\hline ITALY & $\$ 1,308$ & $\$ 1,118$ & $\$ 1,784$ & $\$ 2,363$ & $\$ 1,934$ & $\$ 2,419$ \\
\hline UNITED STATES & 1,359 & 1,262 & 1,542 & 1,787 & 1,756 & 2,045 \\
\hline SPAIN & 1,667 & 643 & 558 & 781 & 962 & 1,815 \\
\hline FRANCE & 1,622 & 1,490 & 2,060 & 2,216 & 2,298 & 2,718 \\
\hline USSR & 1,333 & 1,171 & 1,487 & 1,413 & 1,642 & 851 \\
\hline PORTUGAL & 1,280 & 1,216 & 1,305 & 2,691 & 1,891 & 2,503 \\
\hline LIBYA & 1,457 & 1,286 & 1,406 & 1,588 & 1,775 & 1,800 \\
\hline BRAZIL & 1,467 & 1,392 & 1,458 & 1,712 & 1,780 & 2,392 \\
\hline AUSTRALIA & 1,380 & 1,249 & 1,500 & 1,789 & 1,827 & 1,853 \\
\hline CANADA & 1,606 & 1,425 & 1,784 & 1,948 & 1,815 & 2,062 \\
\hline TOTAL WORLD & 1,086 & 1,012 & 736 & 2,063 & 1,918 & 2,201 \\
\hline
\end{tabular}


LEADING EXPORTERS OF OIIVE OII, $1984-' 89$

\begin{tabular}{|c|c|c|c|c|c|c|}
\hline \multirow{2}{*}{ COUNTRY } & \multicolumn{6}{|c|}{ CROP YEAR } \\
\hline & 1984 & 1985 & 1986 & 1987 & 1988 & 1989 \\
\hline & & & USAND & METRIC & & \\
\hline GREECE & 108 & 53 & 114 & 91 & 32 & 152 \\
\hline ITALY & 82 & 88 & 80 & 91 & 112 & 128 \\
\hline SPAIN & 46 & 270 & 157 & 216 & 282 & 108 \\
\hline TUNISIA & 76 & 46 & 44 & 57 & 52 & 47 \\
\hline TURKEY & 21 & 27 & 29 & 37 & 22 & 37 \\
\hline FRANCE & 3 & 6 & 5 & 6 & 4 & 16 \\
\hline PORTUGAL & 6 & 4 & 9 & 19 & 15 & 9 \\
\hline UNITED STATES & 0 & 0 & 0 & 0 & 0 & 3 \\
\hline JORDAN & 2 & 0 & 2 & 1 & 1 & 3 \\
\hline ALBANIA & 0 & 0 & 1 & 1 & 3 & 2 \\
\hline OTHER WORLD & 13 & 11 & 39 & 123 & 12 & 7 \\
\hline TOTAL WORLD & 357 & 505 & 480 & 642 & 535 & 512 \\
\hline
\end{tabular}

Source: FAO Yearbook: Trade Commerce, Various issues. 
PRICES RECEIVED BY LEADING EXPORTERS OF OLIVE OIL, $1984-189$

\begin{tabular}{|c|c|c|c|c|c|c|}
\hline COUNTRY & \multicolumn{6}{|c|}{ CROP YEAR } \\
\hline & & $--U \cdot S$. & OLLARS $\mathrm{P}$ & METRIC & TONS-- & \\
\hline GREECE & $\$ 1,374$ & $\$ 1,315$ & $\$ 1,617$ & $\$ 2,113$ & $\$ 1,737$ & $\$ 2,218$ \\
\hline ITALY & 1,394 & 1,495 & 1,989 & 2,246 & 1,951 & 2,207 \\
\hline SPAIN & 1,476 & 1,022 & 1,433 & 1,630 & 1,802 & 2,233 \\
\hline TUNISIA & 976 & 1,114 & 1,531 & 1,389 & 1,583 & 1,832 \\
\hline TURKEY & 1,262 & 1,118 & 1,083 & 1,231 & 1,462 & 1,368 \\
\hline FRANCE & 2,065 & 1,980 & 2,601 & 2,576 & 2,867 & 2,522 \\
\hline PORTUGAL & 1,272 & 1,579 & 1,397 & 1,663 & 1,897 & 2,580 \\
\hline UNITED STATES & -- & -- & -- & -- & -- & 716 \\
\hline JORDAN & 1,733 & 1,192 & 1,861 & 1,206 & 1,197 & 1,373 \\
\hline ALBANIA & -- & -- & 1,000 & 818 & 1,091 & 1,182 \\
\hline TOTAL WORLD & 1,332 & 1,181 & 1,614 & 1,939 & 1,812 & 2,126 \\
\hline
\end{tabular}

Source: FAO Yearbook: Trade Commerce, Various issues. 
TABLE X.

WORLD OIIVE OIL SUPPIY \& DISTRIBUTION, 1985-6 to 1990-1.

\begin{tabular}{|c|c|c|c|c|c|c|}
\hline \multirow{2}{*}{ OUTCOME } & \multicolumn{6}{|c|}{ CROP YEAR } \\
\hline & $1985-6$ & $1986-7$ & $1987-8$ & $1988-9$ & $1989-0$ & $1990-1$ \\
\hline & & & HOUSAND & IETRIC & s-- & \\
\hline PRODUCTION & 1,626 & 1,557 & 1,900 & 1,409 & 1,631 & 1,710 \\
\hline EXPORTS & 367 & 545 & 458 & 491 & 463 & 486 \\
\hline IMPORTS & 500 & 572 & 474 & 512 & 528 & 551 \\
\hline CONSUMPTION & 1,718 & 1,768 & 1,772 & 1,762 & 1,804 & 1,769 \\
\hline ENDING STOCKS & 839 & 655 & 799 & 467 & 591 & 597 \\
\hline
\end{tabular}

Figures for 1988-9 are preliminary, figures for 1989-90 \& 1990-1 are forecasts. USDA, FAS. 
TABLE XI .

U.S. OLIVE OIL IMPORTS

BY COUNTRY OF ORIGIN - 1970 TO 1986 (metric tons)

\begin{tabular}{|c|c|c|c|c|c|c|c|c|c|}
\hline Country & 1970 & 1975 & 1980 & 1981 & 1982 & 1983 & 1984 & 1985 & 1986 \\
\hline \multicolumn{10}{|l|}{ EUPOPE } \\
\hline $\begin{array}{l}\text { Italy } \\
\text { Spain } \\
\text { Greece } \\
\text { Other }\end{array}$ & $\begin{array}{r}8938 \\
17210 \\
420 \\
476\end{array}$ & $\begin{array}{r}9472 \\
9103 \\
473 \\
1615\end{array}$ & $\begin{array}{r}14366 \\
8763 \\
485 \\
522\end{array}$ & $\begin{array}{r}16487 \\
8813 \\
578 \\
596\end{array}$ & $\begin{array}{r}16624 \\
8657 \\
519 \\
2045\end{array}$ & $\begin{array}{r}18829 \\
9766 \\
544 \\
2494\end{array}$ & $\begin{array}{r}25678 \\
11168 \\
570 \\
1239\end{array}$ & $\begin{array}{r}28146 \\
11495 \\
715 \\
895\end{array}$ & $\begin{array}{r}35107 \\
10481 \\
903 \\
1016\end{array}$ \\
\hline Total & 27044 & 20663 & 24136 & 26474 & 27845 & 31633 & 38655 & 41251 & 47507 \\
\hline \multicolumn{10}{|l|}{ AFRICA } \\
\hline $\begin{array}{l}\text { Tunisia } \\
\text { Other }\end{array}$ & $\begin{array}{r}1327 \\
0\end{array}$ & $\begin{array}{r}674 \\
0\end{array}$ & $\begin{array}{r}1197 \\
0\end{array}$ & $\begin{array}{r}1196 \\
0\end{array}$ & $\begin{array}{r}1373 \\
0\end{array}$ & $\begin{array}{r}1204 \\
0\end{array}$ & $\begin{array}{r}1450 \\
0\end{array}$ & $\begin{array}{r}1424 \\
0\end{array}$ & $\begin{array}{r}1331 \\
21\end{array}$ \\
\hline Total & 1327 & 674 & 1197 & 1196 & 1373 & 1204 & 1450 & 1424 & 1352 \\
\hline ASIA & N/A & 60 & 0 & 36 & 0 & 268 & 1000 & 1170 & 3091 \\
\hline LAMERICA & N/A & 112 & 102 & 0 & 0 & 8 & 30 & 100 & 201 \\
\hline OTHER & 130 & 125 & 118 & 15 & 19 & $\cdots$ & - & - & 63 \\
\hline TOTAL & 28501 & 21634 & 25553 & 27721 & 29237 & 33133 & 41461 & 43956 & 52214 \\
\hline \multicolumn{10}{|c|}{ PERCENT COMPOSITION - SELECTED COUNTRIES } \\
\hline $\begin{array}{l}\text { Italy } \\
\text { Spain }\end{array}$ & $\begin{array}{l}31.4 \\
60.4\end{array}$ & $\begin{array}{l}43.8 \\
42.1\end{array}$ & $\begin{array}{l}56.2 \\
34.3\end{array}$ & $\begin{array}{l}59.5 \\
31.8\end{array}$ & $\begin{array}{l}56.9 \\
29.6\end{array}$ & $\begin{array}{l}56.8 \\
29.5\end{array}$ & $\begin{array}{l}61.9 \\
26.9\end{array}$ & $\begin{array}{l}64.0 \\
26.1\end{array}$ & $\begin{array}{l}67.2 \\
20.1\end{array}$ \\
\hline Tunisia & 4.7 & 3.1 & 4.7 & 4.3 & 4.7 & 3.6 & 3.5 & 3.2 & 2.5 \\
\hline Other & 3.5 & 11.0 & 4.8 & 4.4 & 8.8 & 10.1 & 7.7 & 6.7 & 10.2 \\
\hline Total & 100.0 & 100.0 & 100.0 & 100.0 & 100.0 & 100.0 & 100.0 & 100.0 & 100.0 \\
\hline
\end{tabular}

Source: FATUS, Foreign Agricultural Trade United States, ERS, USDA, Various Years 
TABLE XIII.

BREAKDOWN OF OLIVE OIL COLLECTED BY ONH BY GRADE $1979 / 80-1987 / 88$

\begin{tabular}{|c|c|c|c|c|}
\hline \multirow[b]{2}{*}{ Grade } & \multirow[b]{2}{*}{$1979 / 80$} & \multirow[b]{2}{*}{$1980 / 81$} & \multirow[b]{2}{*}{$1981 / 82$} & \multirow{3}{*}{$\begin{array}{l}1982 / 83 \\
3284 \quad 14.3\end{array}$} \\
\hline & & & & \\
\hline Super & 43537.3 & $31607 \quad 27.5$ & $5600 \quad 9.9$ & \\
\hline Extra & 31775.3 & $23614 \quad 20.6$ & $7696 \quad 13.6$ & $2115 \quad 9.2$ \\
\hline Fine & 26594.5 & $23068 \quad 20.1$ & $10974 \quad 19.5$ & $2760 \quad 12.0$ \\
\hline ordinary & 46947.9 & $27709 \quad 24.2$ & $24215 \quad 42.9$ & 743132.4 \\
\hline "Lampante" & 4488375.0 & $8592 \quad 7.6$ & $7940 \quad 14.1$ & $7326 \quad 32.1$ \\
\hline \multirow[t]{2}{*}{ Totals } & 59766 & 114590 & 56425 & 22916 \\
\hline & \multirow[b]{2}{*}{$1983 / 84$} & \multicolumn{2}{|c|}{ Year } & \\
\hline Grade & & $1984 / 85$ & $1985 / 86$ & $1986 / 87$ \\
\hline Super & $8640 \quad 7.5$ & $4486 \quad 7.9$ & $15856 \quad 24.4$ & 862712.2 \\
\hline Extra & $11321 \quad 9.9$ & $5807 \quad 10.3$ & $\begin{array}{ll}7974 & 12.3\end{array}$ & $14056 \quad 19.9$ \\
\hline Fine & $\begin{array}{lll}14181 & 12.4\end{array}$ & $3837 \quad 6.8$ & 909914.0 & $12987 \quad 18.4$ \\
\hline ordinary & $42522 \quad 37.1$ & $17333 \quad 30.7$ & $26264 \quad 40.4$ & 2705538.3 \\
\hline "Lampante" & $37883 \quad 33.1$ & $25074 \quad 44.3$ & 5506 & 793111.2 \\
\hline Totals & 114547 & 56537 & 64999 & 70656 \\
\hline
\end{tabular}




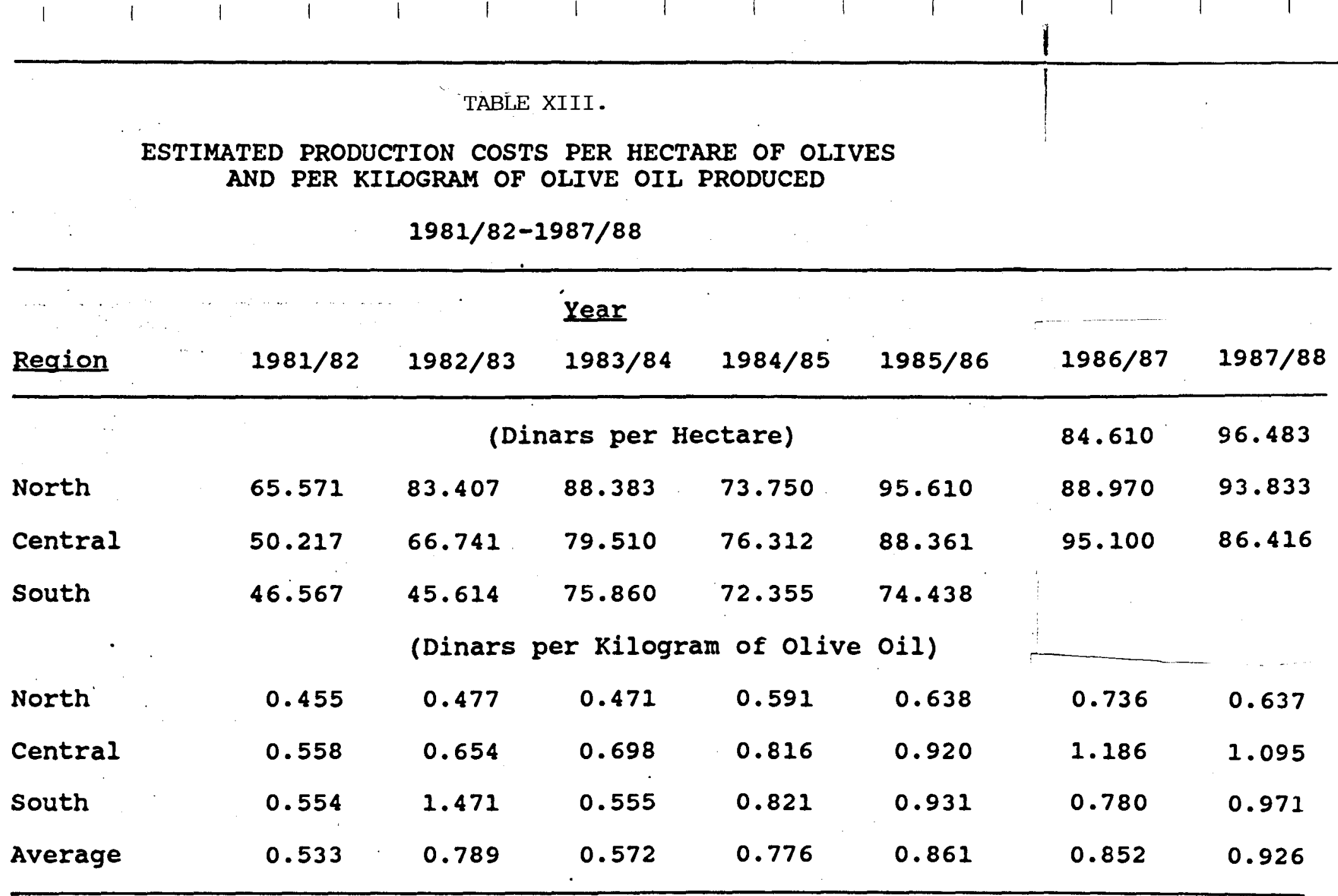

Source: Office National de l'Huile 
TABLE XIV.

World Production of Oranges, Tangerines, and Mandarins, 1970-1986 (in 1000 metric tons)

\begin{tabular}{|c|c|c|c|c|c|c|c|c|c|}
\hline COUNTAY & 1970 & 1975 & 1980 & 1981 & 1982 & 1983 & 1984 & 1985 & 1986 \\
\hline Spain & 2,260 & 2,668 & 2,617 & 2,192 & 2,583 & 3,315 & 2,222 & 3,019 & 3,119 \\
\hline Morocco' & 876 & 617 & 1,024 & 965 & 992 & 934 & 989 & 930 & 1,188 \\
\hline United States & 7,900 & 9,913 & 11,490 & 10,078 & 7,426 & 9,189 & 7,027 & 6,515 & 7,192 \\
\hline Israel & 938 & 1,052 & 1,075 & 871 & 1,199 & 993 & 1,049 & 1,035 & 855 \\
\hline Gaza Strip ${ }^{2}$ & NA & 145 & 142 & 151 & 165 & 139 & 135 & 120 & 120 \\
\hline Greece $^{3}$ & 452 & 578 & 539 & 745 & 703 & 725 & 825 & 678 & 884 \\
\hline Italy & 1,601 & 1,931 & 1,845 & 2,130 & 1,836 & 2,769 & 1,920 & 2,648 & 2,710 \\
\hline Egypt $^{4}$ & 680 & 953 & 991 & 969 & 1,315 & $\overrightarrow{1,349}$ & 1,312 & 1,274 & 1,278 \\
\hline Turkey & 523 & 656 & 858 & 862 & 866 & 974 & 995 & 771 & 870 \\
\hline Mexicos & 1,020 & 2,478 & 2,130 & 1,935 & 2,139 & 2,197 & 1,832 & 1,202 & 1,533 \\
\hline Other & $*$ & & 23,019 & 24,223 & 24,198 & 25,087 & 28,904 & 26,153 & 29,246 \\
\hline Total & $\star$ & $*$ & 45,730 & 45,121 & 43,422 & 47,671 & 47,210 & 44,345 & 48,995 \\
\hline
\end{tabular}

Percent of World Production of Oranges, Tangerines, and Mandarins by Country

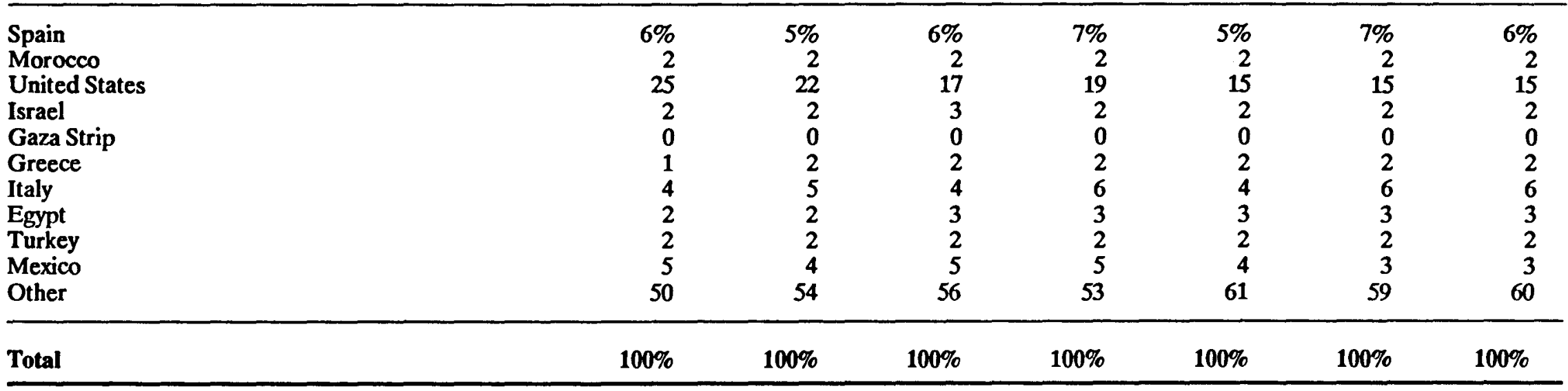

Source: FAO Production Yearbook. Food and Agriculture Organization of the United Nations.

Notes: ${ }^{1}$ Morocco data are unofficial. ${ }^{2}$ Data for the Gaza Strip are unofficial or estimates by the FAO. ${ }^{3} 1985$ is unofficial figure. ${ }^{4} 1975$ and $1984-86$ are unofficial data. ${ }^{1975}, 1980$, and $1984-86$ are unofficial data. "Data not collected. 
TABLE XV.

LEADING PRODUCERS OF ORANGES, 1985-6 to 1990-I.

\begin{tabular}{|c|c|c|c|c|c|c|}
\hline \multirow{3}{*}{ COUNTRY } & \multicolumn{6}{|c|}{ SEASON } \\
\hline & 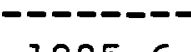 & 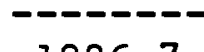 & $-2--2$ & -----1 & -ー-ー-ー-ー & ------ \\
\hline & $1985-6$ & $1986-7$ & $1987-8$ & $1988-9$ & $1989-0$ & $1990-1$ \\
\hline & & & ГHOUSAND & METRIC TC & VS-- & \\
\hline BRAZIL & 11,015 & 10,650 & 10,400 & 14,150 & 12,150 & -ー-ー- \\
\hline UNITED STATES & 6,913 & 7,122 & 7,903 & 8,272 & 7,010 & 7,470 \\
\hline SPAIN & 1,942 & 2,059 & 2,442 & 2,216 & 2,365 & 2,476 \\
\hline MEXICO & 1,410 & 1,683 & 1,942 & 2,268 & 2,200 & 2,400 \\
\hline ITALY & 2,257 & 2,424 & 1,343 & 2,170 & 2,071 & 1,850 \\
\hline EGYPT & 1,168 & 1,235 & 1,387 & 1,199 & 1,397 & 1,400 \\
\hline MORROCCO & 841 & 650 & 891 & 994 & 775 & 890 \\
\hline GREECE & 554 & 881 & 462 & 770 & 933 & 819 \\
\hline ISRAEL & 685 & 815 & 627 & 546 & 877 & 790 \\
\hline TURKEY & 505 & 750 & 700 & 740 & 650 & 750 \\
\hline OTHER WORLD & 2,615 & 2,927 & 2,893 & 3,788 & 3,440 & -- \\
\hline TOTAL WORLD & 29,905 & 31,196 & 30,990 & 36,447 & 33,868 & - \\
\hline
\end{tabular}

Source: USDA, Foreign Agriculture Service. 
World Exports of Oranges, Tangerithes, and Mandarins by Country of Origin, 1970-1986 (in 1000 metric tons)

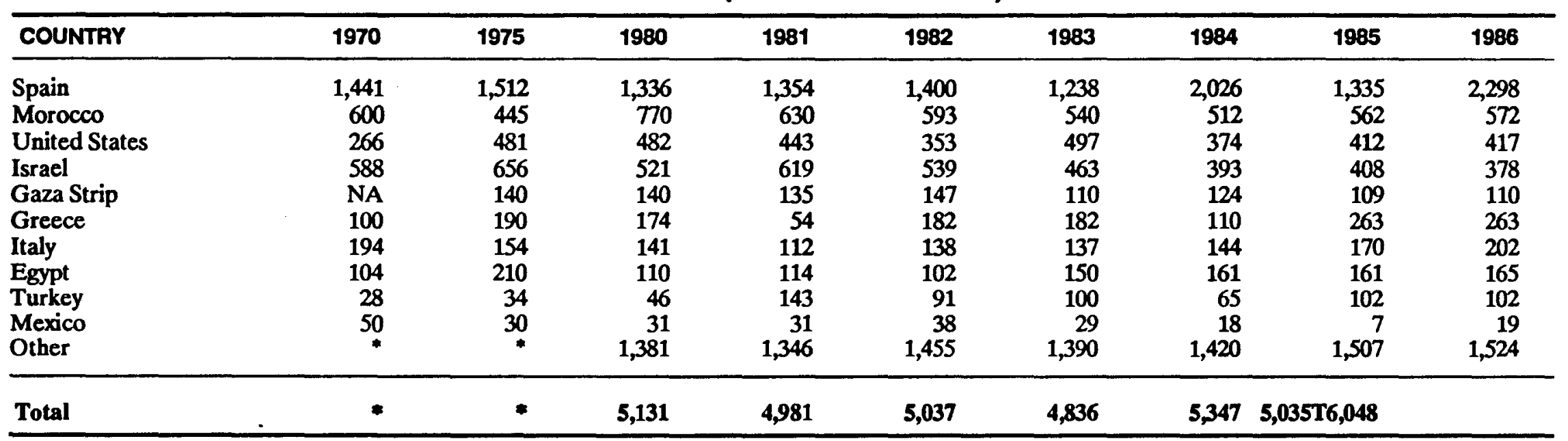

Percent of World Exports Volumes of Oranges, Tangerines, and Mandarins by Country

\begin{tabular}{|c|c|c|c|c|c|c|c|}
\hline Spain & $26 \%$ & $27 \%$ & $28 \%$ & $26 \%$ & $38 \%$ & $27 \%$ & $38 \%$ \\
\hline Morocco & 15 & 13 & 12 & 11 & 10 & 11 & 9 \\
\hline United States & 9 & 9 & 7 & 10 & 7 & 8 & 7 \\
\hline Israel & 10 & 12 & 11 & 10 & 7 & 8 & 6 \\
\hline Gaza Strip & 3 & 3 & 3 & 2 & 2 & 2 & 2 \\
\hline Greece & 3 & 1 & 4 & 4 & 2 & 5 & 4 \\
\hline Italy & 3 & 2 & 3 & 3 & 3 & 3 & 3 \\
\hline Egypt & 2 & 2 & 2 & 3 & 3 & 3 & 3 \\
\hline Turkey & 1 & 3 & 2 & 2 & 1 & 2 & 2 \\
\hline Mexico & 1 & 1 & 1 & 1 & 0 & 0 & 0 \\
\hline Other & 27 & 27 & 29 & 29 & 27 & 30 & 25 \\
\hline Total & $100 \%$ & $100 \%$ & $100 \%$ & $100 \%$ & $100 \%$ & $100 \%$ & $100 \%$ \\
\hline
\end{tabular}

Source: FAO Trade Yearbook. Food and Agriculture Onganization of the United Nations.

Notes: $\quad$ Data for the Gaza Strip are unofficial.

Data not collected. 
TABLE XVII.

LEADING IMPORTERS OF ORANGES, TANGERINES, AND MANDARINES, 1984 -'89

\begin{tabular}{|c|c|c|c|c|c|c|}
\hline \multirow{2}{*}{ COUNTRY } & \multicolumn{6}{|c|}{ CROP YEAR } \\
\hline & 1984 & 1985 & 1986 & 1987 & 1988 & 1989 \\
\hline & & & IOUSAND & ETRIC I & -- & \\
\hline FRANCE & 913 & 800 & 930 & 940 & 964 & 912 \\
\hline WEST GERMANY & 803 & 696 & 805 & 872 & 818 & 830 \\
\hline UNITED KINGDOM & 451 & 406 & 476 & 485 & 535 & 515 \\
\hline NETHERIANDS & 392 & 393 & 441 & 462 & 488 & 500 \\
\hline CANADA & 273 & 259 & 287 & 285 & 251 & 270 \\
\hline USSR & 347 & 366 & 331 & 294 & 288 & 240 \\
\hline BELGIUM-LUXEM . & 183 & 190 & 198 & 212 & 218 & 221 \\
\hline SAUDI ARABIA & 222 & 144 & 103 & 89 & 259 & 200 \\
\hline HONG KONG & 131 & 143 & 156 & 160 & 166 & 167 \\
\hline JAPAN & 89 & 112 & 118 & 124 & 116 & 129 \\
\hline OTHER WORLD & 1,452 & 1,426 & 1,471 & 1,504 & 1,452 & 1,360 \\
\hline TOTAL WORLD & 5,256 & 4,935 & 5,316 & 5,427 & 5,555 & 5,344 \\
\hline
\end{tabular}

Source: FAO Yearbook: Trade Commerce, Various issues. 
TABLE XVIII.

LEADING EXPORTERS OF ORANGES, TANGERINES, AND MANDARINES, 1984 -'89

\begin{tabular}{|c|c|c|c|c|c|c|}
\hline \multirow{2}{*}{ COUNTRY } & \multicolumn{6}{|c|}{ CROP YEAR } \\
\hline & 1984 & 1985 & 1986 & 1987 & 1988 & 1989 \\
\hline & & & IOUSAND & ETRIC I & ;-- & \\
\hline SPAIN & 2,026 & 1,335 & 2,298 & 1,948 & 1,885 & 1,848 \\
\hline MORROCCO & 512 & 562 & 572 & 485 & 579 & 610 \\
\hline UNITED STATES & 374 & 412 & 417 & 403 & 357 & 392 \\
\hline SOUTH AFRICA & 285 & 284 & 300 & 323 & 335 & 336 \\
\hline ISRAEL & 393 & 408 & 378 & 392 & 358 & 313 \\
\hline CUBA & 248 & 270 & 264 & 276 & 260 & 244 \\
\hline TURKEY & 95 & 102 & 102 & 112 & 164 & 170 \\
\hline EGYPT & 161 & 161 & 75 & 167 & 97 & 158 \\
\hline ITALY & 144 & 170 & 202 & 159 & 188 & 155 \\
\hline GREECE & 110 & 263 & 263 & 202 & 95 & 140 \\
\hline OTHER WORLD & 999 & 1,068 & 1,527 & 997 & 984 & 994 \\
\hline TOTAL WORLD & 5,347 & 5,035 & 6,048 & 5,464 & 5,302 & 5,360 \\
\hline
\end{tabular}

Source: FAO Yearbook: Trade commerce, Various issues. 
Volume of U.S. Fresh CitruS YIXPorts by Country of Origin, $1970-1987^{*}$ (in metric tons)

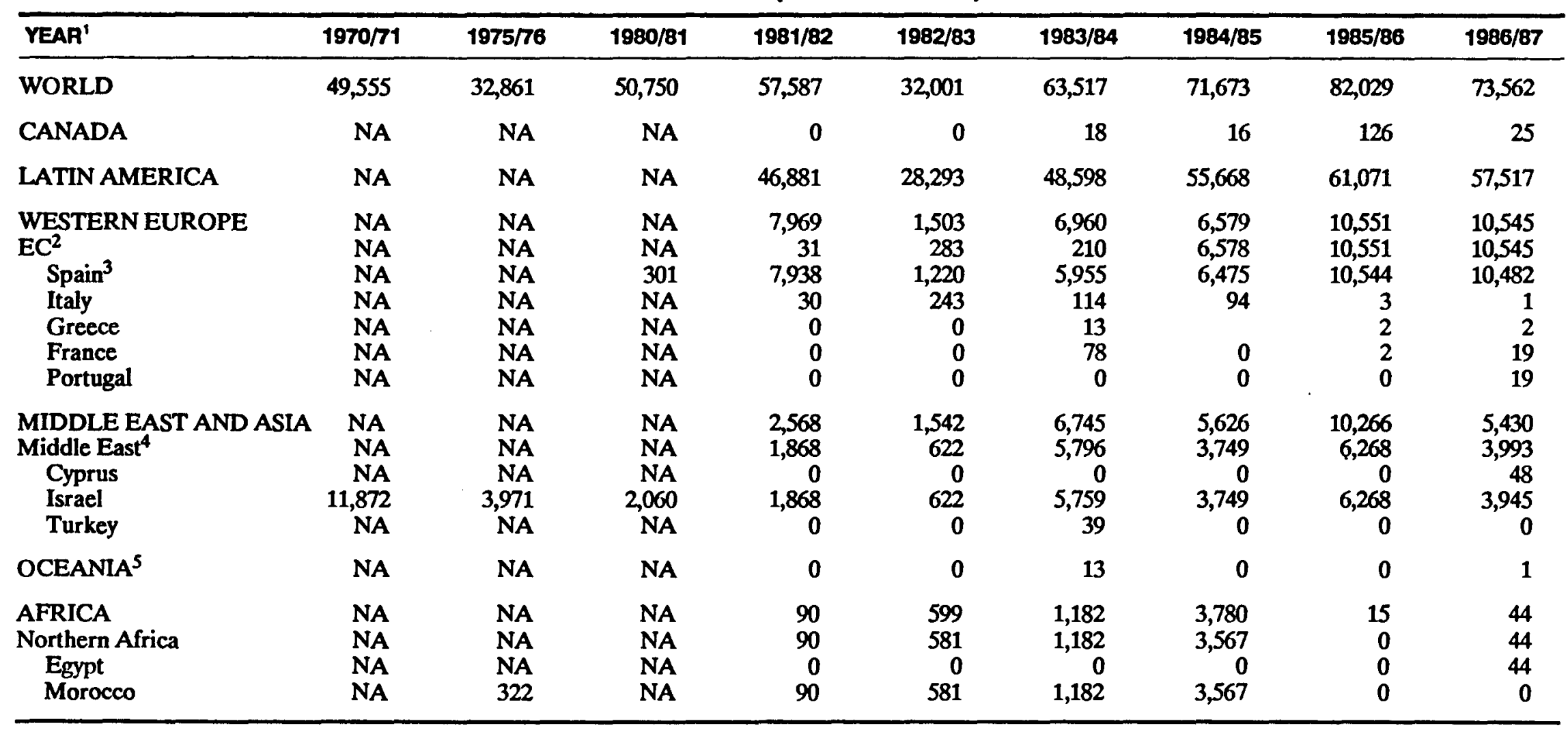

Notes: Zero can be interpreted as an insignificant quantity.

Reporting year nuns from October through September.

1 For period 1970-81, the figures include imports in prepared or preserved form.

Also for 1970-81, the figure for Latin America = Mexico + Equador + Haiti + Jamaica

The number of member countries varies.

3 Including Canary Island which is the primary production area.

${ }_{5}^{4}$ Mainly the Middle East including Israel.

5 Australia and New Zealand.

Sounce: FATUS. USDA. 


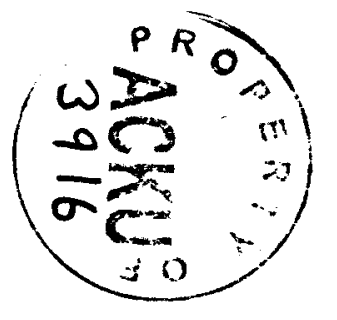

TABLE XX.

Per Capita Citrus Consumption in EEC Countries, 1982/1983 - 1985/1986

(kg/person)

\begin{tabular}{lcccc}
\hline COUNTRY & $1982 / 1983$ & $1983 / 1984$ & $1984 / 1985$ & $1985 / 1986$ \\
\hline Belgium-Luxembourg & 19.2 & 21.9 & 16.8 & 23.1 \\
Denmark & 8.2 & 9.2 & 10.2 & 12.3 \\
France & 20.0 & 0.0 & 17.5 & 21.4 \\
Germany & 27.0 & 29.1 & 26.3 & 29.5 \\
Greece & 64.9 & 37.3 & 60.1 & 35.7 \\
Ireland & 13.2 & 14.5 & 14.7 & 15.8 \\
Italy & 34.4 & 41.3 & 33.5 & 41.5 \\
Netherlands & 93.1 & 80.0 & 81.6 & 84.0 \\
Portugal & 16.0 & 12.3 & 12.9 & 12.8 \\
Spain & 21.7 & 35.3 & 10.4 & 27.8 \\
United Kingdom & 12.9 & 14.4 & 13.5 & 14.5 \\
EEC 12 & & & & 28.9 \\
\hline
\end{tabular}

Source: Agriculture-Statistical Yearbook. Eurostat, 1988. 